\title{
Handan romanında batılılaşmış kadın karşısında batılılaş(ama)mış erkekler
}

\section{Naim ATABAĞSOY}

\begin{abstract}
APA: Atabağsoy, N. (2019). Handan romanında batılılaşmış kadın karşısında batılılaş(ama)mış erkekler. RumeliDE Dil ve Edebiyat Araştırmaları Dergisi, (14), 68-77. DOI: 10.29000/rumelide.540995
\end{abstract}

\section{$\ddot{O} \mathbf{z}$}

Türk edebiyatında roman türünde eser veren yazarların Batılılaşma meselesine yoğun olarak ilgi gösterdiği görülür. Bu aynı zamanda, özellikle 19. yüzyılın ikinci yarısı ve 20. yüzyılın başlarında toplumsal olarak Batılılaşmaya yönelik mevcut eğilimin bir tezahürüdür. Toplumdaki bu yenileşme sürecinde kadının konumu da elbette sorgulanmış ve bu konu edebiyatta, çoğunlukla romanlar aracılığıyla karşımıza çıkmıştır. Bu anlamda çalışma, kadın hareketlerindeki görünürlüğüyle de bilinen Halide Edip Adıvar’ın mektuplaşmalar biçiminde kaleme alınmış 1912 tarihli romanı Handan'ı odağına almaktadır. Romanın merkezindeki karakter olan Handan'ın kendisini birbirinden farklı şekillerde arzulayan ve Batılılaşmış görünen erkek karakterlerle sorunlu ilişkisi, modernleşme sürecinde kadının toplumdaki konumunu da sorgulamaya iter. Romanda Nâzım, Hüsnü Paşa ve Refik Cemal karakterleri, bu süreci Batı'yı yüzeysel biçimde taklit ederek tecrübe eden erkek karakterlerdir. Bu erkek karakterler, toplumdaki yeni tip erkeği farklı şekillerde temsil ederken buna paralel gelişen yeni kadın tipini çelişkili biçimde özümseyememektedirler. Handan, toplumsal meselelerde fikirleri olan iyi eğitimli bir kadındır. O, geleneksel çizgideki hemcinslerine kıyasla erkeklerle daha rahat iletişim kurar, erkeklerin de bulunduğu meclislerde serbestçe görüşlerini açıllar, üstelik onlarla tartışmalara girmekten geri durmaz. Handan bu yönleriyle Nâzım'da, Hüsnü Paşa'da ve Refik Cemal'de belirgin bir çekince uyandırır. Çalışma Handan'ın bu üç erkekle ilişkisine, erkeklerin bu yeni toplumsal süreçte kadınlar karşısındaki çelişkili tutumuna ve Handan'ın gelenek karşısındaki konumlanışına eğilmektedir.

Anahtar kelimeler: Kadın hareketi, batılılaşma, Türk romanı, gelenek.

\section{(Non)westernized men against westernized woman in the novel Handan}

\begin{abstract}
Turkish novelists seem to be deeply involved in the question of Westernization. That is, at the same time, a reflection of the social tendency towards Westernization, through the second half of the 19th century and early 2oth century. The position of woman in society was also examined through that innovation period, and many novels emphasize this problem. In this respect, the article focuses on the novel Handan, which is in the form of correspondence and was first published in 1912, written by Halide Edip Adıvar, who is a prominent figure in women's movement. The novel's main character Handan's problematical love affairs with Westernized-like men desiring her in various ways, prompt us to question the position of woman in society in the modernization period. The novel characters Nâzım, Hüsnü Pasha and Refik Cemal shallowly imitate West through that same period. On one hand, those characters represent a new-type man in society in various ways, but on the other, inconsistently, they cannot internalize the new-type woman. Handan is a well-educated woman who has ideas on
\end{abstract} ooo2-4832-2717 [Makale kayit tarihi: 11.01.2019-kabul tarihi: 16.03.2019; DOI: 10.2900o/rumelide.540995] 
social issues. Unlike other women in society representing traditional values, she feels comfortable in her conversations with men, she expresses her opinions freely in men's gatherings; besides, she does not refrain from entering into discussions with men. With all those aspects, Handan causes an obvious hesitation for Nâzım, Hüsnü Pasha and Refik Cemal. This article focuses on Handan's love affairs with those three male characters, men's contradictory manner towards women in this new social context, and Handan's positioning in respect of tradition.

Key words: Women's movement, westernization, Turkish novel, tradition.

\section{Giriş}

Modernleşme sürecini tecrübe eden her toplumda olduğu gibi Osmanlı toplumunda da kadının toplumdaki yerinin tartışmaya açılması elbette doğal bir sonuçtur. Osmanlı'da Batılılaşma hareketlerinin görülmeye başladığı 19. yüzyıldan itibaren toplumsal, siyasi, ekonomik sahalarda birçok yenilikçi adım atılmış, bunu izleyen süreçte de kadının kamusal alanda görünürlüğü ve sosyal, entelektüel çevrelerdeki varlığı tartışmaya açılmıştır. Söz konusu tartışmaya açılma süreci aynı zamanda, kadınların kendi hakları için verdikleri uzun ve zorlu bir mücadeleye de işaret etmektedir. Bu açıdan, öncelikle kadın haklarıyla ilgili günümüzdeki -ne ölçüde mümkün olduysa- kazanımlara bakıldığında, bu hakların kadınlara lütfedilmediği, her kazanımın bir hak arayışının sonucu olduğu ve kadınların hak mücadelesinin farklı düzeylerde devam ettiği hatırlanmalıdır. İşte söz konusu mücadele süreci, çoğu kez pedagojik bir misyon yüklenmiş olan Tanzimat dönemi edebiyat eserlerinde izlenebilmekte, takip eden süreçte de edebiyat eserlerine böylesi bir misyonun yüklenmiş olduğu görülebilmektedir. Tanzimat döneminde edebiyat alanında eser veren Fatma Aliye ve Emine Seniye Hanım gibi önemli isimler, aynı zamanda kadın hareketleriyle ilişkili sosyolojik malzemeyi de önümüze koyarlar ${ }^{2}$.

Halide Edip Adıvar’nn yaşamı ve verdiği eserler dikkate alındığında kadın hakları ve kadın özgürleşmesi konularında aynı çizgiye yerleşen bir yazar olduğu görülür. Adıvar, bütünüyle feminist bir çizgide eser veren bir yazar olarak değerlendirilmese de, kendi döneminde kadın haklarıyla ilgili kayda değer girişimleri olduğu ve bunu eserlerine de yer yer yansıttığı yadsınamaz. 20. yüzyılın başından itibaren Müdafaa-i Hukuk-u Nisvân ve Teâli-i Nisvân gibi kadın cemiyetlerinin kurulmasında öncülük eden Adıvar'ın romanlarında da kadın karakterler ön plandadır. İşte Halide Edip Adıvar'ın ilk olarak 1912 ylında Tanin gazetesinde tefrika edilen Handan romanı da, merkezine Batılılaşmış bir kadın karakteri koyar. Handan, Türk edebiyatında kadının Batılılaşması sorununu radikal biçimde ele alan bir metin olması bakımından kayda değerdir. Özellikle Şerif Mardin’in (2006) Tanzimat döneminde kaleme alınan romanlarda Batılılaşmış üst sınıf erkek tipiyle birlikte kadının toplumsal statüsünün iki temel sorun olduğu yönündeki görüşü (s. 30) dikkate alınırsa, Handan'da kadının toplumsal statüsünün tartışlıyor olması, Tanzimat sonrası dönemden günümüze kadar uzanan bu sorunun kesintisiz biçimde gündemde kaldığını gösterir3.

\footnotetext{
2 Osmanlı'da kadın haklarılla ilgili verilen mücadeleyi kadın yazarlar üzerinden anlatan kayda değer bir çalışma için bkz.: Avcı, M. (2016). "Osmanlı Devleti’nde Kadın Hakları ve Kadın Haklarının Gelişimi İçin Mücadele Eden Öncü Kadınlar." A.Ü. Türkiyat Araştırmaları Enstitüsü Dergisi 55, 225 - 254.

3 Günümüze değin, Handan romanını konusu itibariyle Halide Edip’in özel yasantısıyla birlikte ele alan değerlendirmeler olmuşsa da, bu tür bir yaklaşımın hâlâ önemini koruyan kadının toplumdaki konumu meselesine gölge düşüreceği açıktır. Cevdet Kudret Türk Edebiyatında Hikâye ve Roman: 1859 - 1959 adlı çalışmasında (2016), Handan romanını Halide Edip’in eşi Salih Zeki'den ayrıldıktan sonra kaleme aldığına dikkati çeken değerlendirmeler yapıldığını dile getirmiştir (s. 380). Bu yaklaşımlar kuşkusuz, araştırmacıları edebiyat metninin değerinden, dolayısıyla toplumsal çözümlemeler ve bilimsel değerlendirmeler yapma imkânından uzaklaştırır.
} 
Romanın başkarakteri Handan, iyi eğitimli, erkeklerle eşit biçimde kamusal alanda görünürlüğü sıradanlaştırmış ve onlarla entelektüel tartışmalara katılabilen, bu özellikleri dolayısıyla da erkekler tarafından yadırganan bir karakterdir. İlginç biçimde bu, "Batılılaşmış" erkeğin "Batılılaşmış" kadını, yine Batılılaşmış kimliği dolayısıyla kabullenememesi durumunu ortaya çıkarır. Romanı radikal bir konuma getiren, Handan'ın o dönemde toplumun ön gördüğü sınırları aşan bir kadın karakter olmasıdır. Ancak bununla birlikte, Batılılaşmış erkeğin yukarıda işaret edilen çelişkisi, yani kendisinin sahip olduğu (ya da sahip olduğunu düşündüğü) değerlerin temsilcisi olan bir kadını o kimliğin tüm içerikleriyle birlikte bir bütün olarak kabul edememe durumu, metni daha da ilgi çekici kılar.

Romanda özellikle erkek karakterlerle anılan Batılılaşma kavramına eğilmek, bu kavramın neye işaret ettiğini kavramak gerekmektedir. Bilindiği gibi Osmanlı'daki Batı ilgisinin, savaşlarda Batılı devletlere karşı özellikle teknolojik bakımdan karşı koyamama sonucu askerî bir nitelikle başladığı söylenegelmiştir. Bunu eğitimde ve sosyal hayatta devlet politikası olarak yürütülen yenileşme hamleleri (yeni tarzda eğitim veren okullar açmak, gayrimüslim tebaaya karşı hukuksal açıdan eşitlikçi bir tutuma yönelmek vb.)4 takip etmiştir. Bir anlamda Batılılaşma süreci kendine özgü ve doğal bir süreç içerisinde değil, devletin varlığını sürdürme kaygısı çerçevesinde sistematik olarak ilerleme gayreti göstermiştir.

$\mathrm{Bu}$ durum kuşkusuz toplumdaki Batı ilgisinin de sorunlu ve yapay olmasına yol açmıştır. Osmanlı olmanın Batılı olmaya engel teşkil edip etmeyeceği tartışması bir kenarda tutulacak olursa, Batılılığın özünün kavranamaması ya da Batılı olmanın ne demek olduğu konusu müphem kalmıştır. Dolayısıyla Batılı yaşam tarzının yüzeysel ve görünür yanlarını kendi yaşamlarına adapte edenler, Batılılaşmış kimseler olarak değerlendirilmişlerdir. Nitekim Handan romanında da Batılllaşmaya ilişkin simgelerin (Fransızca konuşmak ya da piyano çalmak gibi) aynı şekilde yüzeysel bir boyutta kaldığı söylenebilir.5

Öte yandan Osmanlı ve Avrupa toplumları, bu yazının odağında yer alan kadının toplumsal konumuyla ilgili mücadeleler çerçevesinde kıyaslanırsa aralarında çok büyük farklar olmadığı anlaşılır. Fatmagül Berktay'ın "Osmanlı'dan Cumhuriyet'e Feminizm” başlıklı yazısında işaret ettiği üzere (2014) örneğin, kadınların oy hakkı talebi Batı'da 20. yüzyıldan önce karşılık bulmaz, ya da söz gelimi miras konusunda evli kadına mülkiyet hakkının tanınması İngiltere'de ancak 1882'de gerçekleşir (s. 351, s. 352). Başka bir deyişle kadınların hakları ve hürriyetleri için mücadeleleri Batı'da da devam etmektedir. Adıvar'ın kaygısı işte tam da kadınların hak ve hürriyet talebi doğrultusunda önem kazanır. Romanda okura kendi bireyliğinin ve özgürlüğünün sınırlarını sorgulatan Handan, Halide Edip’in toplumdaki yenileşme hareketlerine zihinsel bir pencereden baktığını ve Batı’yı, bireylerin hak ve özgürlüklerinin savunulması penceresinden değerlendirerek önemsediğini gösterir. ${ }^{6}$

$4 \quad$ Esasında bu hamleler, temelinde bireyin bütüncüllüğü ve aklın özgürleşmesi gibi bir fikir altyapısını barındıran modernleşme düš̈ncesinin Osmanlı'daki yansımalarıdır. Osmanlı yüzünü Batı'ya çevirdiğinde modernleşmenin bu getirileriyle karşlaşmış ve uygulamalarında modernliğin düşünsel olmasa da somut tezahürlerini görmek mümkün olmaya başlamıştır.

$5 \quad$ Batı'yı belirli parçalar üzerinden öğrenmeye çalıșmakla ilgili soruna Hilmi Yavuz (2005) "Medeniyet: Parça mı, Bütün mü? (Yaban'ı Yeniden Okurken)" başlıklı makalesinde yer verir. Yavuz, Tanzimat ve Servet-i Fünûn romanlarında görülen piyano çalmak ve Fransızca konuşmak gibi niteliklerin “Avrupalı olmanın simgesel işaretleri” olarak değerlendirilmesine vurgu yapar. Yavuz, buradan yola çıkarak Türk Modernleşmesinin (ya da Batılılaşmasının) metonimik bir Batılılaşma olduğunu ifade eder (s. 79). Buna göre piyano çalmak, şapka giymek, Fransızca konuşmak gibi özelliklerin Batılı olmanın "parça"sı olabileceğine, ancak Avrupalılı̆̆ı "bütün”üyle temsil edemeyeceğine işaret eder. Bir bakıma Türk Modernleşmesi, Batılılaşmayı "somut" ve "görünür" simgelerle kavrar; ancak bir medeniyeti temellendirmek "soyut" kavramlarla mümkündür (s. 8o). Medeniyetin bu kendine özgü kavramlarını bilim, felsefe, demokrasi, insan hakları ve sivil toplum olarak sıralayan Yavuz, medeniyetin, "somut"a ait olan yaşam tarzına indirgenemeyeceğini belirtir (s. 80).

$6 \quad$ Tanıl Bora (2017) da Cereyanlar kitabında Halide Edip Adıvar'ın bu özgün yönünü vurgulamakta ve onun, Batı'nın özünü "ilim zihniyeti ve haklar-hürriyetler perspektifinde” (s. 79) aradı̆̆ına işaret etmektedir. 
Roman, İngiliz terbiyesiyle yetişmiş, yanı sıra Arapça, müzik ve din eğitimi de almış olan Handan'ın zevk ve eğlenceye düşkün Hüsnü Paşa ile yaptığı mutsuz evlilik ve Refik Cemal ile arasında gelişen yasak aşkı konu alır. II. Abdülhamid istibdadına karşı sergilediği duruşunda ve sosyalizme yönelik "maksad" ında Handan'ı yanında görmek isteyen Nâzım ve onun Handan'a yaptığı evlilik teklifi de romanda geri dönüşlerle verilmektedir. Kısacası Handan'ın çevresinde, onunla farklı biçimlerde ilişki kuran üç erkek bulunmaktadır. Bu bağlamda ortaya çıkan çerçevede, metnin Batılılaşan kadın figürü merkezinde Batılılaşan erkeğe bakma olanağı da sağladığı söylenebilir.

Bu çalışmada, söz konusu olanaktan faydalanarak Batılılaşan erkeğin kadına bakışı düzlemi üzerinden kadın karakter Handan'ın toplumda kendisi için tayin edilen sınırları aşan bir kadın birey olarak ne ölçüde yalnız bırakıldığı tartışılacaktır. Böylelikle aynı zamanda, Batılılaşmada kadının konumu ve Batılılaşan kadın karşısında aynı değer kümesini temsil eder görünen erkeğin içinde bulunduğu çelişki de görünür kılınacaktır. Bunu yaparken erkek karakterlerin Batılılaşma göstergelerinin (bir Batı dili bilmek ya da bir Batı çalgısı çalmak vs.) yüzeyselliği de kendini gösterecektir.

Çalışmada göz önünde bulundurulacak bir başka önemli nokta, romanın son kısmında ifade bulan, geleneksel anlayışın sözü edilen yeni değerler kümesine nasıl baktığı meselesidir. Geleneksel bakış açısının, kadının talep ettiği yeni konuma henüz onay vermeyip Batılılaşmış erkeklerle birlikte onu yalnızlaştırma sürecine destek olduğu görülür. Burada ilginç olan, geleneksel bakış açısının kadın özgürleşmesine tepkisinden ziyade, Batılılaşmış erkeklerin bu bakış açısıyla örtük bir ortaklığının bulunmasidır.

\section{Handan: Özgür ve yalnız bir kadın}

Romanın başlangıcında, bulunduğu çevrede Cemal Bey'in “alafranga” kızlarından biri olarak tanındığı belirtilen Handan'ın hayatına giren Batılılaşmış erkek karakterleri Handan merkezinden incelerken Handan'ın romana nasıl yerleştirildiğinin görülmesi önem taşımaktadır. Handan ile ilgili romanda sıkça tekrarlanan bir özellik onun erkeksi olarak nitelendirilen davranışlarıdır. Örneğin Refik Cemal, NotreDame Kilisesi'nde Handan'la karşılaştığı sahneyi yazdığı mektupta eşi Neriman'a anlatırken Handan'ın, elini bir erkek gibi sıktığını vurgular (Adıvar, 2008, s. 33). Aynı mektubunda Handan'la ilgili şunu da ekler:

"Handan pek iyi, pek nazik, akıllı bir kadın; fakat kadın da pek diyemeyeceğim. Lakırdı söylerken, düşünürken onun kadın olduğunu bile insan düşünemiyor" (Adıvar, 2008, s. 34).

Refik Cemal'in daha sonra birlikte yasak bir aşk ilişkisi içine gireceği Handan'la ilgili ilk değerlendirmeleri bu şekildedir. Öte yandan Neriman'a yazdığı mektupta Handan'ın kendisi için benzer bir nitelemeyi yaptığı görülür. Hocası Nâzım ile çıktıkları gezide kendisini ata bir "erkek gibi oturttu[klarından]" söz eder (Adıvar, 2008, s. 51). Neriman da bir mektubunda "Handan'ın cinsiyetini pek kimse düşünmez, erkek gibi kız” diyecektir (Adıvar, 2008, s. 65). Bu değerlendirmelerde kadının toplumsal alandaki etkin görünüş biçiminin geleneksel algıda yarattığı yabancılaştırıcı etki kendini gösterir. Handan, çevresindeki kimseler her ne kadar Batılılaşmış birey temsilleri olarak görülseler de, edimleri dolayısıyla aynı kimseler tarafından geleneksel bakış açısıyla kadın kimliğinin sınırlarını aşan bir figür olarak algılanır ve cinsiyetinden soyutlanarak kendisine erkeklik atfedilir.

$\mathrm{Bu}$ durum, hem romandaki Batılılaşmış karakterlerin çelişkisine hem de Handan'ın ortaya koyduğu toplumdaki yeni kadın kimliğiyle birlikte bir yabancılaştırmaya ve yalnızlaştırmaya maruz kaldığını gösterir. Handan kendisine erkeklik atfedilmesi düzeyinde aslında özgürleşmiş kadın kimliğini ortaya 
koymakta, fakat bu çıkışı kabul görmemektedir. Beyhan Uygun Aytemiz "Handan: Ataerkil Söylemin Kıyısında Biçimlenen Roman” başlıklı makalesinde bu yabancılaştırma meselesinin en net şekilde Refik Cemal karakterinde kendini gösterdiğini şu sözlerle ifade eder:

Kendi tekellerinde gördükleri bilim, sanat, felsefeyle ilgilenmeyen kadını aşağılayan, ilgilenen ve bu konularda yetkin kadınıysa bir rakip ve düşman olarak gören ataerkil düşünce yapısı Refik Cemal'in anlatısında açıkça hayat bulur (Uygun Aytemiz, 2010, s. 19).

Söz konusu alanlarla ilgili tartışmalara katılan kadınların "erkeksi” bulunduğunu belirten Uygun Aytemiz (s. 20), kadının kamusal alandaki görünürlügüyle ilgili yenilikçi fikirlere sahip olması beklenecek bu erkek karakterlerin, hâlâ bir çelişki içinde olduklarını Refik Cemal karakteri üzerinden vurgulayarak yeni nesil Osmanlı erkeğinin çalışmamızın da merkezine oturan büyük çelişkisine işaret etmiş olur.

Handan'ın özgürleşmiş kadın kimliğini ortaya koymasına örnek olarak, erkekten kaçma vakti geldiği zaman dahi babasının dostlarıyla görüşmesi ve dostluk etmesi gösterilebilir (Adıvar, 2008, s. 41). Neriman bunun yanı sıra Handan'ın öğrenmek konusundaki hırsına ve hocaları dolayısıyla kazandığı donanıma vurgu yapar. Neriman, Handan'da bilmeye "susamış bir dimağ" olduğunu ve çeşitli hocalardan "musiki, edebiyat, felsefe, içtimaiyat" gibi dersler aldı̆̆ını belirtir (Adıvar, 2008, s. 41). Neriman'ın entelektüel donanım konusunda Handan’ı kendisinden üstün görmesi, toplumsal alanda Handan'ın romandaki diğer kadınlardan daha rahat bir şekilde bulunabilmesi, yapacağ konusunda inisiyatif kullanabilmesi, onun Batılılaşma sürecinde özgürleşmiş bir kadın figürü vücuda getirdiğini göstermektedir.

Bununla birlikte unutulmamalıdır ki, Handan'ın şahsında inşa edilen yeni, özgürleşmiş kadın figürü, İslâmî değerler yönünden geleneksel bakış açısına bütünüyle uzak değildir. Ramis Karabulut (2017), "Halide Edib Adıvar'ın Romanlarında Sosyal Bir Mesele Olarak Din/İslam” başlıklı makalesinde Handan'ın misafir olduğu Selim Bey'in evinde, onunla İslâm üzerine yaptığı sohbetler yoluyla herkesi kucaklayan evrensel bir din anlayışını tanıdığına vurgu yapar (s. 182). Handan, ibadet pratikleri ve tasavvuf üzerinden İslâm'ın düşünsel yorumları hakkında donanım sahibidir. Dinin her yönünü tanımış ve İslâm hakkında belli bir görüş sahibi olmuştur. Bir başka deyişle, Handan'ın şahsında Halide Edip, diğer romanlarında da karşımıza çıkan bir izleği ortaya koymuş ve geleneksel değerleri tümüyle dışarıda tutmayan bir yenileşmenin imkânlarını tartışmaya açmıştır. Handan'ın özgürleşmiş kadın kimliğine ve bu kimliğin nasıl karşılandığına dair Handan merkezinden bir bakış ortaya konulduğuna göre, romandaki Batılılaşmış karakterlerin çelişkilerine ve erkeklerle ilişkileri üzerinden Handan’ın yalnızlaştırılma sürecine daha yakından bakılabilir.

Handan romanına bu şekilde yaklaşırken Yakup Kadri Karaosmanoğlu'nun roman ile, daha özelde Handan karakteri ile ilgili yorumunu göz önüne almak, onun erkeklerle ilişkilerini anlaşılır biçimde ortaya koymak bakımından yararlı olacaktır. İnci Enginün (1978) Halide Edip Adıvar’n Eserlerinde Doğu ve Batı Meselesi adlı çalışmasında Yakup Kadri'nin şu sözlerini aktarır: "Bu beyin, sinir ve ruhtan mürekkep bir kadın ki üç defa sevmiş, mesela bir kere beyninden, bir kere sinirlerinden, bir kere de ruhundan sevmiş" (s. 126) Handan'ın, Hüsnü Paşa, Refik Cemal ve Nâzım'la olan ilişkilerini tahlil ederken onun Hüsnü Paşa'yı sevmesini tabii bulur ve Handan'ın "hakiki bir kadın” olarak romanda yansıtılabilmiş olmasını buna bağlar (s. 126). 
Handan'ın erkeklerle ilişkilerin incelemek için yardımcı olabilecek bu izlekten gidilecek olursa, Handan'ın erkeklerle söz konusu ilişkilenme biçimlerine dair Yakup Kadri’nin getirdiği "beyin-sinirruh” kategorizasyonunun tutarlı olduğu görülür. Zira Handan'ın Nâzım'da bulduğu güzellik onun büyük fikirleriyle ve kendini bir amaca adamasıyla ilgilidir. Handan'ın Hüsnü Paşa'yla ilişkisinin ise romanda bedensel (Yakup Kadri’nin "sinirsel” diye tabir ettiği) düzeyde bir ilişki olduğu görülür. Refik Cemal’le Handan'ın ilişkisine bakıldığında, Handan'ın hasta ve güçsüz olduğu, ilgiye muhtaç olduğu bir evrede Refik Cemal'in aşkının zirveye ulaştığı görülür. Burada Handan ve Refik Cemal'in yakınlaşması Yakup Kadri'nin işaret ettiği gibi daha çok ruhsal -ya da duygusal diyeceğimiz- bir düzeydedir. Handan'ın ilişkilenme biçimlerini romana dayanarak gösterirken Handan'ın yalnızlaştırılma sürecine ve Batılılaşmış bireylerin çelişkilerine daha yakından bakma imkânı doğacaktır.

\section{Handan'ın Batılılaşmış ve Çelişkili Erkekleri}

İlk olarak Handan'ın evlilik teklifini reddettiği Nâzım'la ilişkisine yakından bakılırsa, Nâzım'ın Handan'ı nasıl konumlandırdığı daha iyi anlaşılır. Handan’ın hocası olan Nâzım, Handan’a evlilik teklif ederken fikirlerini ve "maksad"ını ön plana çıkarır:

Handan Hanım, ben sizinle evlenmek istiyorum. Bunu evvela Cemal Bey'e söylemek lazımdı. Fakat size söylemekte bir maksad-ı mahsusam var. Bu evlenmek her evlenmek gibi olmayacak. Şeraiti belki her genç kızın isteyeceği gibi değil. [...] Fakat sizi tetkik ettim, gördüm ki siz mesleğe, paraya değil hayata, efkâra, büyük maksatlara arkadaş olacak kızlardansınız. Onun için size bu akşam söylemeye cesaret ediyorum (Adıvar, 2008, s. 69-70).

Görüldüğü gibi Nâzım'ın evlilik teklifinde Handan'ı sadece fikir yönünden değerlendirme ve onu bir dava arkadaşı gibi görme durumu söz konusudur. Teklif Handan'a değil, Handan'ın temsil ettiği kimliğin entelektüel donanım boyutuna ilişkin görünmektedir. Nitekim Handan da Nâzım’ın yarattı̆̆ bu çelişkili durumun farkındadır ve Neriman'a yazdığı mektubunda evlilik teklifine değindikten hemen sonra teklifi yorumlar: "Bana teklif ettiği bu izdivaçta eksik bir şey vardı: Beni maksadıyla evlendiriyordu, beni kendiyle değil!” (Adıvar, 2008, s. 70). Evlilik teklifi sahnesinde Handan, Nâzım'ın önerisini "maksad”ı ön planda olması ve evlilik bağını sağlayacak olan "sevmek" yönünü bulamaması nedeniyle reddeder. Kuşkusuz aldığı teklif Handan'ı, iki insanın birbirini sevmesi sonucu aldığı bir teklif olmaması bakımından rahatsız eder. Evlilik teklifinde Nâzım'ın kendisini değil, fikirlerini görmektedir. Elbette aynı durum Nâzım için de geçerlidir.

Nâzım ideallerini savunan aydın bir karakter olarak romanda yer alır. Handan, Nazım için "onun zengin ve canlı dimağı Garbın ve Şarkın esrar felsefesinden ve sanatından renk ve şekil alarak önümüzde akarken ben sarhoştum” (Adıvar, 2008, s. 48) yorumunu getirir. Nâzım’ın Doğu ve Batı kültürleri konusundaki donanımı Handan'ın bir başka tespitinde şu biçimde yansır:

Onun arzularına, hayatına, nazariyelerine şekil veren şeyler hep Alman, Fransız ve Şark'ın ebedi simaları, benimkiler ise nispeten daha az, fakat o kadar ezeli ve büyük birkaç İngiliz siması (Adıvar, 2008, s. 52).

Bu tespitte Handan'ın Nâzım'ın entelektüel donanımı karşısında duyduğu saygı ve ilgi belirginleşir. Handan, Batılılaşma sorunsalını ele alan romanlarda Batılılaşmış karakterlerde sıkça görülen bir davranış biçimi olarak Nâzım'la birlikte piyano çalar (Adıvar, 2008, s. 49). Fakat Nâzım, Batılı değerlerin yanında Doğu'yu da özümsemiştir. Ancak tüm bu ortaklıklar ve Handan'ın Nâzım'ı, Doğu'yu ve Batı'yı entelektüel düzeyde birlikte kavramış bir aydın kişilik olarak idealleştirmesi bir araya gelmelerine yetmez. Zira Handan'ın tek beklentisi düşünsel örtüşme değildir. Başka bir deyişle Handan'ın, Nâzım'ın evlilik teklifini reddetmesi, sahip olduğu özgürleşmiş kadın kimliğiyle 
araçsallaşmayı reddetmesi anlamına gelir. Handan bir anlamda bu kimliğiyle, ideolojik bir söylemin yedeğindeki bir ilişkilenme biçimini reddetmiş olur. Üstelik Nâzım evlilik teklifini gündeme getirirken ona hocalık etmesine dayanarak Handan'a "[S]izi bu parlak ve nihayetsiz efkârınızla ben yaratmış kadar7 benimsedim," (Adıvar, 2008, s. 72) diyecektir. Dolayısıyla Handan ilişkisinde, Nâzım tarafından anlaşılamamış ve yalnızlaştırılmış olur.

Nâzım karakterinin yukarıdaki sözlerini Serpil Sancar'ın Türk Modernleşmesinin Cinsiyeti adlı kitabında, yazarın geç Osmanlı ve Cumhuriyet dönemi üzerine çalışmasıyla öne çıkan Ayşe Saraçgil l'den aktardığı bir tespiti sunarken dile getirdiği görüşle anlamlandırmak mümkündür. Sancar’ın aktarımıyla Saraçgil:

Osmanlı erkeğinin eğitip kölelikten kurtararak özgürleştirdiği kadını (tıpkı kölesini eğitip azat eden köle sahibi gibi) kendine eş yapmasının temel konu edinildiğini belirtir. Erkek kahramanlar, kadınları kurtarıcı bu tavırları karşılığında, kendi kafasına uygun olarak ideal kadın-eş yaparken, erkeğe tüm varlığı ile bağlı, sadık ve minnettar olmalarını arzulamışlar[dır] (akt. Sancar, 2012, s. 129).

Sancar'ın yukarıda aktardığı tespit, Handan’ı kendisinin “yarattığını” dile getiren Nâzım’da âdeta vücut bulur. Bu bakımdan Nâzım’ın temsil eder göründüğü yeni aydın tipi konumu tartışmaya açık hâle gelir. Zira Sancar'ın (2012) çalışmasında vurguladı̆̆ı üzere modernleşme eğilimi gösteren Osmanlı erkeğinin tavrı, konu kadınların modernleşmesi olduğunda çelişkili bir görünüş sergiler (s. 128). Bu durumdaki erkek âdeta modernleşme sürecinin doğasına aykırı olarak kadının kendisi kadar modernleşmiş olmasını arzu etmemektedir.

Handan'ın mutsuz bir evlilik süreci geçirdiği Hüsnü Paşa'ya eğilecek olursak evvela Yakup Kadri’nin ortaya koyduğu tespite işaret etmek gerekir. Hüsnü Paşa'nın Handan’a gösterdiği alakanın tensel boyutta olması kayda değerdir. Zira Hüsnü Paşa’nın taşıdığı bu ilgi onun Handan'la yaptığı evlilikteki tavrında sıklıkla karşımıza çıkar. Hüsnü Paşa evliliğine Handan kadar sadık ve Matmazel Juliette adında bir metresi vardır. Hüsnü Paşa'nın Batılılaşmaya dair taşıdığı unsurlar romanda bu şekilde yansıtılırken taşıdığı özellikler çerçevesinde Handan’a duyduğu ilgi şu sözleriyle belirginleşir:

\begin{abstract}
Seni temin ederim ki senin bu kadar şiddetle hissettiğin sıkı ve mukaddes rabita-i izdivacın kutsiyetini, bağını ben hiç hissetmedim. [...] Seni bir kadın diye sevdim, bir kadın diye sevmediğim zamanlarda bıraktım. [...] Sen cazibedar kadınsın, sen bende nihayetsiz arzular uyandırırsın, hülasa Handan'sın. Şimdi bu satırları sana yazarken henüz pek sevdiğim metresim dışarıda beni beklerken yine senin kokunu, senin temasını, senin sesini hatırladım, arzuladım. [...] Fakat aldanmıyorum, bu sadece bir arzu (Adıvar, 2008, s. 140).
\end{abstract}

Hüsnü Paşa, Handan'a yönelik tutumunu ona karşı açıkça dile getirmekten çekinmez. Öte yandan Handan'ın Hüsnü Paşa'yla arasındaki evlilik bağına sadık kaldığı unutulmamalıdır. Handan, eşi Hüsnü Paşa'ya asla ihanet etmez. Hatta Refik Cemal'e duyduğu aşk, ancak hastalığı sırasında artık saklanamaz hâle gelecektir. Tüm bunların ötesinde Handan, başlangıçta "dünyanın gözünü korkutmuş bir adama hâkim oluvermek hissi” (Adıvar, 2008, s. 74) duysa da henüz evliliğinin başında Hüsnü Paşa'nın "bir kadının vücudu gibi ruhu[nun] da kocasının sahası" (Adıvar, 2008, s. 132) olduğu yönündeki tahakkümcü görüşünü kabullenmiş görünmektedir. Kısacası Handan’ın bu ilişkisinde de özgürleşmiş kadın kimliğini tam olarak ortaya koyamadığı, yine yalnızlaştırıldığı görülür. Hüsnü Paşa ise yalnızca tensel bir ilgi beslediğini ifade ettiği Handan'la evlenmek istemekle çelişkili bir durumun içerisinde görünür. Zira Handan’ı kişilik olarak tümden görmezden gelen ve gösterişsiz düğünlerinden başlayarak

Cümledeki vurgular bana ait.

Saraçgil, Ayşe (2005), Bukalemun Erkek, Osmanh İmparatorluğu’nda ve Türkiye Cumhuriyeti’nde Ataerkil Yapılar ve Modern Edebiyat, çev. S. Aktaş, İletişim Yayınları. 
“derin bir keder”e (Adıvar, 2008, s. 75) sürükleyen yeni devrin adamı Hüsnü Paşa9, Handan’ın inşa ettiği yeni kadın kimliğine aldırmaz görünmektedir.

$\mathrm{Bu}$ aşamada Batılılaşmış tiplerden Refik Cemal'e değinmek yerinde olacaktır. Refik Cemal de vaktini Londra'da geçirir ve burada bulunduğu süreçte bir dil problemi yaşamaz. Konuşurken ve yazarken, dönemin Batılılaşmış erkek tipine uygun düşecek biçimde Fransızca ifadelere başvurur ${ }^{10}$. Bununla beraber kadınlarla ilgili fikirlerinde gelenek bilincinden tam bir kopma yaşadığı da söylenemez. Handan'ın sergilediği kendinden emin havadan bir yandan rahatsız olmakla beraber diğer yandan da eşi Neriman'ı Handan'dan daha yetersiz gördüğü için eleştirir:

\begin{abstract}
Kadınlar ne acayip mahluklar, ruhlarında ne çok muhtelif şeyler için ayrı ayrı yerler var. Biz zavallı erkekler için bu bir felaket. Fakat nankör olmamalı, Neriman hiç öyle değildir. Bilirim ki onun ruhunda benden, Nâzım'dan ve sevgili yeğeni Handan'dan başka hiçbir şey için yer yoktur. Yalnız bu yer, nasıl söyleyeyim, zavallı Neriman! Bu yerde otura otura insanın canı sıkılıyor. Handan ise kökü kazınmaz, hiçbir şeye kanmaz vefalarına rağmen o kadar muhtelif şeylerle hayatını doldurabiliyor ki (Adıvar, 2008, s. 147).
\end{abstract}

Refik Cemal'in Handan'la ilişkisinden anlaşılıyor ki, kendisi kadının toplumsal meselelerle ilgili fikir yürütmesi ve paylaşması taraftarı olmakla birlikte Handan’ın "erkeksilik” niteliği atfedilen özelliklerini sergilemesini onaylamamaktadır. Zira ona göre "kadınlar daima rakik, emin bir himaye altında korunmaya muhtaçtırlar[...]” (Adıvar, 2008, s. 34). Nitekim romandaki bir diğer Batılılaşmış erkek karakter olan arkadaşı Server'e yazdığı mektupta Handan’a duyduğu “ümitsiz ve şifasız” (Adıvar, 2008, s. 148) sevgiden bahsedebilir konuma gelirken Handan'mn hasta ve güçsüz bir durumda olduğuna da dikkat edilmelidir. Refik Cemal bir yandan Batılı değerlere yakın ve kadının toplumdaki konumuyla ilgili modern fikrî eğilimlere sahip olmasına rağmen Handan’la ilişkisinde kadının, erkeğin himayesinde olması gerektiği inancı ön plana çıkar. Bunun yanında, Handan’ı en çok himaye altında tutabileceği bir anda onunla yakınlaşması en üst düzeye ulaşır. Refik Cemal yenilikçi fikirlere sahip olsa da yaşam pratiğinde taşıdığı fikirlerin tam karşısında yer alacak şekilde, himayeye muhtaç "çaresiz kadın" figürünün kendisi için makbul olduğu görülür. Metindeki bu durum da Refik Cemal’in çelişkisi olarak öne çıkar. Handan ise yine özgürleşmiş kadın kimliğini ortaya koyamayacağı bir ilişkilenme biçimi içinde yalnızlaştırılmış olur.

\title{
Geleneğin karşısında Handan
}

Handan'ın sağladığı kadın merkezli Batılılaşma okuması olanağına eklemlenecek bir başka bağlam olduğuna başlangıçta değinilmişti. Batılılaşma meselesine toplumdaki geleneksel bakış açısının tepkisini ortaya koyan romanın son sahnesi, romanda gelişen sürecin tümüne bir başka açıdan, Handan'ın içine yeni bir kadın kimliğinin tohumlarını ekmeye çalıştığı toplumsal alanın penceresinden bakma olanağı sunar. Cemal Bey’in komşusu Hacı Murat'ın evinde geçen konuşmada Handan'ın ölümü üzerine Murat Efendi'nin karısının yaptığı şu yorum dikkat çekicidir: “Cemal Bey'in alafranga kızlarının büyüğü değil mi? İmansızlığın sonu budur, efendi. Acımana şaşıyorum. Allah ona ahrette yatacak yer verecek mi sanıyorsun? Bütün ömrü gavur memleketlerinde geçti” (Adıvar, 2008, s. 215). Bu ifade yazar Halide Edip’in, geleneksel bakış açısının Batılılaşmaya nasıl tepki gösterdiğini vurgulaması bakımından

\footnotetext{
$9 \quad$ Hüsnü Paşa'yı “yeni devrin adamı” şeklinde nitelendirirken hemen belirtmek gerekir ki, Hüsnü Paşa Batılılaşma adı altındaki bu yenileşmeyi de özümseyememiş ve yanlış değerlendirmiş bir karakterdir. Bununla birlikte karşısındaki yenileşmiş kadın kimliğini de görmezden gelmesi, yenileşmeyi kavrayışındaki yüzeysellik ve eksiklik dolayısıyla esasında anlaşlır bir durumdur.

10 Örnek olarak romanda Server karakterine yazdığı bir mektubu "Bonnuit, Server" (İyi geceler, Server) (Adıvar, 2008, s. 89) diye bitirir.
} 
ilginçtir. Yazar böylelikle Batılılaşmanın gelenekle arasına toplumsal yaşam bağlamında bir set çekilmiş olduğunu ifade eder.

Halide Edip’in romanın son bölümüne yerleştirdiği bu bakış açısı, esasında özgürleşmiş kadın kimliğinin henüz kendini ortaya koyamamasının önemli nedenlerinden birini açıklamış olur. Toplumdaki gelenekçi yaklaşım, "alafrangalık" şeklinde ifade bulan Batılılaşmaya ve kadının özgürleşmesi meselesine mesafelidir. Buradan elbette Halide Edip'in geleneksel toplumu olumsuz bir eleştiriye tabi tuttuğu anlamı çıkmaz. Yazar mevcut toplumsal şartların, Handan’ın ortaya koymaya çalıştığı kadın kimliği için hazır olmadığına işaret etmiş olur. Yukarıda belirtildiği üzere, metinde gelenekçi toplumsal bakış açısına yönelik olumsuz eleştirinin yokluğu bu görüşü desteklemektedir.

Gelenek, alafrangalığa ve kadının özgürleşmesine yazarın bakışı çerçevesinde bu şekilde tepki göstererek bir anlamda kadını Batılılaşma mücadelesinde yalnız bırakır. Ancak çalışmamızın da esasını oluşturan nokta hatırlanacak olursa, kendisini Batılılaşmış ve yenilikçi, özgürlükçü kimlikte sunan erkeklerde dahi aynı yalnızlaştırma davranışının görülmesi, kadın özgürleşmesine yönelik gelenekçi tavrın pek de şaşırtıcı olmadığını gösterir.

\section{Sonuç}

Halide Edip Adıvar'ın, Handan romanında kadının Batılılaşması meselesini, merkeze aldığı bir kadın karakter dolayımında yakından mercek altına aldığı görülür. Merkezdeki kadın karakter olan Handan üzerinden, yüzünü Batılılaşmaya dönen özgürleşmiş kadın temsilinin görünürde Handan gibi Batılılaşmış olan erkekler tarafından nasıl sorunlu bir şekilde değerlendirildiği de bu şekilde anlaşılmış olur.

Handan'ın Batılılaşmış erkeklerle ilişkilenme biçimlerinde, benzer entelektüel donanımlara ve bakış açlarına rağmen inşa ettiği yeni kadın kimliğini bütünüyle kabul ettiremediği görülür. Romandaki üç erkek karakter de birbirinden farklı düzeylerde Batılılaşmış tipler olmakla beraber, üçünün de Handan'ın özgürleşmiş kadın kimliğini benimseyememeleri dikkat çekicidir. Nâzım’ın Handan'a fikir düzeyinde beslediği arzu, Hüsnü Paşa'nın bedensel arzusu, Refik Cemal'in kadının erkek tarafından himaye edilmesine dayanan tahakkümcü ruhsal arzusu söz konusudur; ancak Handan'ın ilişki yaşadığı erkeklerden hiçbiri Handan'ı özgürleşmiş, ama değerlerinden de kopmamış yenilikçi kadın kimliği içinde bütünüyle kabul etmeyi beceremez. Handan tüm ilişkilerinde sahip olduğu kimliği bütünüyle tecrübe edemediği ve bu bakımdan da yalnızlaştığı bir pozisyona çekilir.

Daha önce de vurgulandığı üzere, gelenekçi toplumsal tabanın bakış açısı, henüz yeni kadın kimliği konusundaki bir atılıma hazır değildir. Bu durum Halide Edip tarafından kuşkusuz tuhaf karşılanmamaktadır. Yazarın burada vurgulamak istediği, Handan'da vücut bulan özgürleşmiş, yeni kadın temsilinin gelenekçi toplumsal tabanla bir çatışma içinde olmasıdır. Nitekim romandaki başkarakter Handan, kadın özgürleşmesi konusunda çağının gereği olan bir tartışmayı ortaya koysa dahi, kadın özgürleşmesinin bugüne uzanan ve edebiyatta da yansımaları olan tarihi hesaba katıldığında yine de erken bir örnek olarak karşımızda durmaktadır. Bu bakımdan, romanda Murat Efendi’nin karısının söyleminde vücut bulan gelenekçi bakış açısına ilişkin yabancılaştırıcı bir yaklaşım söz konusu değildir. Öyle görünüyor ki Halide Edip’in asıl vurgusu, görünürde fikirsel olarak yaşadıkları çağın yeni fikirlerini benimsemiş kimseler olmaları ön görülecekken, kendileriyle aynı düşünsel pozisyondaki kadın kimliğini ötekileştiren erkeklerin içinde bulunduğu çelişkili durum üzerinedir. Burada yürütülen çalışma da, söz konusu çelişkili duruma ve bu durumun dolaylı etkilerine eğilmeye çalışılmıştır. 


\section{Kaynakça}

Adıvar, H. E. (2008). Handan. (2. Baskı). M. Kalpaklı ve G. E. Korkmaz (Haz.). İstanbul: Can Yayınları. Berktay, F. (2014). "Osmanlı'dan Cumhuriyet'e Feminizm”. Modern Türkiye'de Siyasî Düşünce Tanzimat ve Meşrutiyet'in Birikimi: Cilt 1. (10. Baskı). İstanbul: İletişim Yayınları, s. 348 - 361.

Bora, T. (2017). Cereyanlar - Türkiye'de Siyasî İdeolojiler. (2. Baskı). İstanbul: İletişim Yayınları.

Cevdet Kudret. (2016). Türk Edebiyatında Hikâye ve Roman: 1859 - 1959. İstanbul: Kapı Yayınları.

Enginün, İ. (1978). Halide Edip Adıvar’n Eserlerinde Doğu ve Batı Meselesi. İstanbul: İstanbul Üniversitesi Edebiyat Fakültesi Yayınları.

Karabulut, R . (2017). "Halide Edib Adıvar'ın Romanlarında Sosyal Bir Mesele Olarak Din / İslam". Karadeniz Uluslararası Bilimsel Dergi, 36 (36), 176-201.

Mardin, Ş. (2006). Türk Modernleşmesi: Makaleler 4. (16. Baskı). İstanbul: İletişim Yayınları.

Sancar, S. (2012). Türk Modernleşmesinin Cinsiyeti. İstanbul: İletişim Yayınları.

Saraçgil, A. (2005). Bukalemun Erkek, Osmanlı İmparatorluğu'nda ve Türkiye Cumhuriyeti'nde Ataerkil Yapılar ve Modern Edebiyat. S. Aktaş, çev. İstanbul: İletişim Yayınları.

Uygun Aytemiz, B. (2010). "Handan: Ataerkil Söylemin Kıyısında Biçimlenen Roman”. Roman Kahramanları, 3 (Temmuz/Eylül), 17-23.

Yavuz, H. (2005). “Medeniyet: Parça mı, Bütün mü? (Yaban’ı Yeniden Okurken)”. Edebiyat ve

Sanat Üzerine Yazılar. İstanbul: Yapı Kredi Yayınları. 